\title{
correspondence
}

\section{Evolving evolution}

SrR,-A science writer who spends his life recording the repeated triumphs of unorthodoxy must complain about the tone of R. A. Crowson's remarks on molecular evolution and anti-Darwinism (Nature, 254, 464; 1975). The simplest fault is the most telling : throughout his attack on Ohta, Crowson refers to "him"-but Ohta is a woman. That is a symptom of the lack of ordinary personal communication between the "neutralists" and "selectionists".

There is a lack of scientific communication, too. Crowson makes much of alleged discrepancies between the fossil record and the dates used by Dickerson and by Wilson et al. in their molecular chronologies. As Dickerson himself pointed out forcibly: "The zoologists who have the best command of information on dates have maintained a reserved scepticism towards the entire protein endeavour."

The language Crowson uses is improper for a scientific argument. Concerning his quotation on "the demons of the underworld, chance and probability", one wonders where physicists would be today had they shunned those demons and looked only to "the heavenly powers"? Most perturbing is his phrase "potentially dangerous to our science", applied to the work of Kimura, Ohta and others. Dangerous to whom? To a biological Establishment unwilling to rewrite its lecture notes? If science does not live dangerously, open always to rebuttal and revision, it quickly ceases to be science.

Neo-Darwinism has shown signs of hardening into quasi-religious dogma of a kind that Darwin would surely have repudiated; witness Crowson's phrase about "the historic truths of evolution". Fortunately, discoveries and ideas have kept the blood circulating, not only the puzzling intraspecific and interspecific variations in molecular structure but, in a quite different direction, the violation of the canon against group selection in explanations of social behaviour.

I don't know whether the "neutralists" are correct or not, but then no one does. What I do observe is that some of the critics of Kimura and Ohta react like priests scenting blasphemy. Which really is "dangerous to our science" : bold hypotheses which eventually can be thrown out if wrong, or theories too sacred to question?

Crawley, Sussex, UK

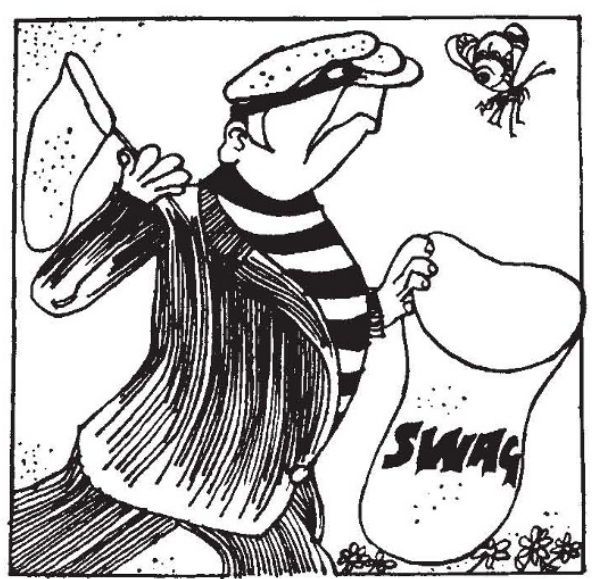

\section{Butterflies lost}

SIR,-In 1974 about 15 butterflies were stolen from the Museum National d'Histoire Naturelle in Paris. All the specimens were rare and beautiful Ornithoptera and Papilio. The museum is understandably anxious to trace their whereabouts and puts their value at 30,000 francs (about $£ 3,000$ ).

Butterflies, it seems, are nowadays treated like postage stamps. Rare and beautiful tropical species are in great demand, and on a world basis the buying and selling (and stealing) of specimens is a growth industry. There are big dealers in many countries, particularly in the United States and Japan but also in Britain, and there are numerous smaller dealers and 'contacts' in tropical countries. For many years Taiwan has been at the centre of the trade, and business in Brazil is said to amount to 50 million specimens a year. The demand is almost exclusively for large and showy species. The wings are often made into jewellery (cufflinks, brooches and rings) or are used to decorate trays.

Hardly anything is known of the size of butterfly populations or if species are endangered by massive exploitation for profit; few countries have laws that restrict the import and export of specimens. Years ago the birds of paradise and other beautiful and exotic birds were brought to the verge of extinction by collectors and dealers, but legislation was eventually introduced and it is not easy nowadays to trade in them. Must we wait until some of the most beautiful creatures on Earth are nearly extinct before we take steps to stop the trade?

Leicester, UK

\section{Nitrogen fixation}

SIR,-Current biochemical and genetic attempts to develop nitrogen-fixing bacteria symbiotic with plants now lacking them (some described by John Postgate, Nature, January 31, p. 305) raise a significant question.

Sir Peter Medawar has said that when developing a new technology, one should try to imagine the consequences if one succeeded beyond one's wildest dreams. Suppose we developed efficient, enthusiastic, and promiscuous nitrogen-fixing bacte $\mathrm{r}$ a which, rather than confining their attention to a few agricultural crops in specific areas, became widespread in distribution and in effect on the planetary nitrogen cycle. What then?

Those of us who respect the extensive design experience reflected in present arrangements for fixing nitrogen-even more than we respect man's ingenuity in altering them-might rephrase the question more simply. If some plants are not now leguminous, might there not be a reason for it? If there were a better kind of nitrogen cycle, would it not already be here?

AMory B. Lovins

Friends of the Earth Limited,

London, UK

\section{Citation}

Sir,-Cawkell (April 3) defends citation analysis largely on the grounds that through repeated co-citation groups of articles come to be "the putative "core' literature of the subject".

With my youthful idealisms now lost in the mists of time I regard repeated co-citations with suspicion if not with cynicism. Here I find myself in sympathy with E. Chargaff (Nature, 248, 776-779; 1974). He expressed the view that bibliographies were once comparatively honest but that there is a growing tendency for groups of references to be 'lifted' from one publication to the next. The growth of the scientific literature is such that it is difficult for an author to be fully conversant with the content of all articles that may have a bearing on his work. The citing of papers that have not been read cannot, however, be condoned; it leads not only to spurious 'cores' (well exemplified in my own field of study) but also to spurious reputations. A citation should imply an author's personal opinion on the relevance of the cited publication.

E. F. HARTREE 